\title{
Diagnosis Hama dan Penyakit Tanaman Bawang Merah Menggunakan Sistem Pakar
}

\author{
Moh Jasri ${ }^{1}$ \\ ${ }^{1}$ Departemen Sistem Informasi, Universitas Nurul Jadid \\ Email : moh.jasri@unuja.ac.id
}

\begin{abstract}
Abstrak-Penelitian ini mencoba membuat sebuah sistem pakar untuk mendeteksi hama dan penyakit yang ada pada tanaman bawang merah dengan merancang sebuah design secara maksimal dengan menggunakan DFD, ERD, serta block diagram untuk menemukan sistem yang bisa digunakan untuk mendiagnosa hama dan penyakit pada tanaman bawah merah, adapun teknik diagnosa yang digunakan dalam penelitian ini menggunakan forward chaining.

Forward Chaining adalah teknik penelusuran yang dimulai dari fakta-fakta terlebih dahulu baru menjurus pada sebuah kesimpulan, Sedangkan Block diagram yang dibuat berfungsi untuk membatasi area permasalahan dalam penelitian ini, untuk menerapkan block diagram kedalam sebuah sistem database selanjutnya adalah merancang DFD dan ERD agar block diagram bisa diterapkan pada database dan aplikasi.
\end{abstract}

Kata Kunci-Sistem Pakar, Diagnosa, Bawang Merah, Visual Basic

\section{Pendahuluan}

$\mathrm{I}^{2}$ ndonesia merupakan salah satu negara penghasil rempahrempah terbersar di dunia melihat dari kesuburan tanah yang ada pada negara Indonesia merupakan anugerah pemberian tuhan yang patut di syukuri, sehinga mayoritas masyarakat Indonesia bercocok tanam atau petani, akan tetapi budidaya petani indonesia yang kurang maksimal disebabkan oleh kurangnya pengelolaan terhadap perkembangan serta pertumbuhan tanaman sehingga banyak petani yang kurang sukses,untuk mengembangkan reproduksi, minimnya penyuluhan serta peranan pemerintah untuk mengembangkan usaha petani, agar dapat terwujud kesejahteraan terhadap masyarakat indonesia dan sesuai dengan apa yang diharapkannya.

Bawang merah merupakan komuditas pertanian dengan nilai ekonomis yang cukup tinggi juga tidak terbebas dari hama dan penyakit yang setiap saat bisa merusak tanaman bawang, sehingga bisa menyebabkan gagal panen. Pada awalnya petani membasmi hama dan penyakit tanaman dengan cara sederhana yaitu dengan cara fisik dan mekanik sebagai bentuk reaksi pertahanan alami bagi petani. Namun semakin meluasnya pertanian cara-cara penanggulangan secara sederhana tersebut tidak mampu untuk membendung peningkatan populasi dan keganasan hama dan penyakit tanaman bawang merah. Oleh karena itu peran dinas pertanian perlu untuk melakukan sosialisasi atau pemberitahuan tentang masalah hama dan penyakit tanaman serta pengendaliannya.
Masalah kegagalan panen atau kerusakan tanaman akibat serangan hama telah merupakan budidaya pertanian. Bercocok tanam tujuannya adalah untuk diambil hasilnya bagi pemenuhan kebutuhan sandang dan pangan dengan kuantitas dan kualitas yang terus ditingkatkan sesuai dengan perkembangan kehidupan manusia, salah satunya adalah pengendalian hama dan penyakit yang dilakukan secara maksimal yaitu dengan diperlukannya pakar-pakar pertanian yang banyak memanfaatkan kemajuan teknologi informasi dengan menjadikan seperangkat komputer sebagai sebuah system yang ahli dalam bidang pertanian.

Khususnya pada Kecamatan Gending yang merupakan salah satu daerah yang penduduknya mayoritas bekerja sebagai petani, dan merupakan penghasil tanaman bawang merah terbanyak di kabupaten Probolinggo dibandingkan daerah lainnya. Namun tidak jarang petani di khawatirkan oleh hama dan penyakit yang menyerang tanamannya bawang merah tersebut, jika hama dan penyakit tidak segera diatasi maka akan menimbulkan kerugian bagi para petani.

Serangan hama dan penyakit dapat di atasi dengan cepat apabila petani mampu mengidentifikasi jenis hama dan penyakit yang menyerangnya secara cepat, dan berdasarkan pada gejala-gejala yang muncul hingga dampak yang ditimbulkan bisa diminimalisir sedini mungkin, dalam dunia komputer tindakan yang cepat dan tepat dalam mengidentifikasi hama dan penyakit tersebut dapat di wujudkan melalui pembuatan sistem pakar, akan tetapi tujuan utama sistem pakar bukan untuk menggantikan kedudukan seorang pakar melainkan memasyarakatkan pengetahuan dan pengalaman seorang pakar.

Sistem pakar (expert system) adalah usaha untuk menirukan seorang pakar dan sangat ideal bagi seseorang yang harus mengambil keputusan terbaik dari serangkaian pilihan atau alternatif yang ada, dalam perkembangannya sistem pakar lebih maju dibandingkan dengan pengembangan kecerdasan buatan yang lain dan sekarang ini sistem pakar telah digunakan dalam berbagai aplikasi seperti diagnosis, instruksi, interpretasi, monitoring, perencanaan peramalan, pengendalian dan perbaikan, biasanya sistem pakar berupa perangkat lunak pengambil keputusan. ide dasarnya adalah kepakaran ditransfer dari seorang pakar, ke komputer, pengetahuan yang ada disimpan dalam komputer dan pengguna dapat berkonsultasi pada komputer. kemudian komputer akan dapat mengambil referensi (menyimpulkan, mendeteksi dan lain-lain) seperti layaknya seorang pakar. Kemudian menjelaskannya ke 
pengguna tersebut.

Sistem pakar terkadang lebih baik kerjanya dari pada seorang pakar manusia, sampai saat ini sudah ada beberapa hasil perkembangan sistem pakar dalam berbagai bidang sesuai dengan bidang kepakaran seseorang, misalnya bidang kedokteran, peternakan dan lain-lain, aplikasi dalam bidang pertanian seperti dalam laporan penelitian penelitian ini didasarkan atas banyaknya petani bawang yang mengalami kerugian karena tidak mengetahui hama dan penyakit apa yang menyerang tanamannya serta bagaimana solusi penyembuhannya. Aplikasi ini digunakan dalam tambahan informasi bagi penyuluh pertanian.

\section{LANDASAN TEORI}

Bawang merah diduga berasal dari daerah Asia. sebagian literatur menyebutkan bahwa tanaman bawang merah ini dari Asia tengah, terutama Palestina dan India, tetapi sebagian lagi memperkirakan asalnya tanaman bawang merah ini dari Asia Tenggara. Nara sumber lain menduga asal usul bawang merah ini dari Iran dan pegunungan sebelah utara Pakistan, namun ada juga yang menyebutkan asal tanaman ini dari Asia Barat dan Mediterranean, yang kemudian berkembang ke Mesir dan Turki. tidak ada catatan resmi sejak kapan bawang merah mulai dikenal dan digunakan. Namun diduga telah dikenal sejak lebih dari 5000 tahun yang lalu, di mesir kunopun sudah banyak orang menggunkan bawang merah untuk pengobatan. di Yunani sudah mengenal bawang merah ser 4000 tahun yang lalu[5].

Dari berbagai penelurusan dalam literature dan nara sumber, terdapat kesamaan pandang bahwa bawang merah merupakan tanaman yang tertua dari silsilah budi daya tanaman oleh manusia. Hal ini antara lain ditunjukkan pada zaman I dan II dinasti (3.200-2.700 SM). Bangsa Mesir sering melukiskan bawang merah pada patung dan tugu-tugu mereka. Sedangkan di Israel dikenal pada tahun 1.500 SM.

Penelitian ini mencoba membuat sistem pakar untuk mendeteksi infeksi penyakit bawang merah sehingga bisa ditangani secepatnya. Adapun pengertian dari Sistem pakar (expert system) merupakan cabang dari kecerdasan buatan (Artificial intelligence) dan juga merupakan bidang ilmu komputer saat ini. Sistem pakar sebagai kecerdasan buatan, menggabungkan pengetahuan dan fakta-fakta serta teknik penelusuran untuk memecahkan permasalahan yang secara normal memerlukan keahlian dari seorang pakar. Tujuan ilmu AI adalah membuat sesuatu menjadi cerdas dalam hal pemahaman melalui program komputer yang ditunjukkan dengan tingkah laku cerdas. Hal ini berkenaan dengan suatu konsep dan metode inferensi simbolik atau penalaran yang dilakukan oleh komputer,dan berkenaan juga dengan bagaimana merepresentasikan suatu hasul kesimpulan pengetahuan ke dalam suatu mesin komputer[2]. Sistem pakar adalah sistem komputer yang bisa menirukan atau menyamai kemampuan seorang pakar [2]. Sistem pakar juga bekerja untuk mengambil pengetahuan manusia ke komputer yang menggabungkan dasar pengetahuan (Knowledge base) dengan sistem inferensi untuk menggantikan seorang pakar dalam menyelesaikan suatu masalah[2]. Program AI yang mencapai kemampuan tingkat pakar dalam menyelesaikan suatu permasalahan dengan menghasilkan suatu pengetahuan tantang masalah yang spesifik dinamakan basis pengetahuan (Knowledge-based) atau sistem pakar. Sistem pakar merupakan sistem yang berbasis pengetahuan, yaitu sistem yang meniru penalaran dari seorang pakar dalam bidang tertentu. Sistem ini menggunakan pengetahuan manusia untuk menyelesaikan masalah yang biasanya memerlukan kepakaran seorang ahli [2].

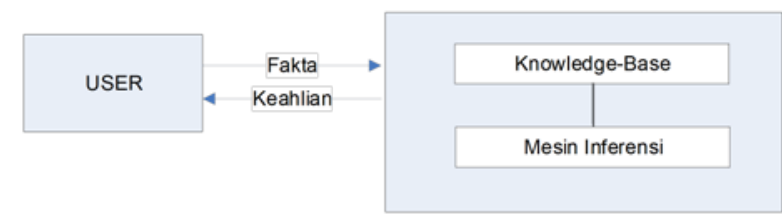

Gambar. 1. Konsep Dasar Fungsi Sistem Pakar

Untuk memahami bagaimana cara kerja dari sistem pakar bisa dilihat pada Gambar 1, Gambar 1 merupakan diagram Dasar dari fungsi sistem pakar atau gambaran umum sistem pakar, untuk lebih detailnya bisa lihat pada Gambar 2, Gambar 2 merupakan arsitektur dari sistem pakar.

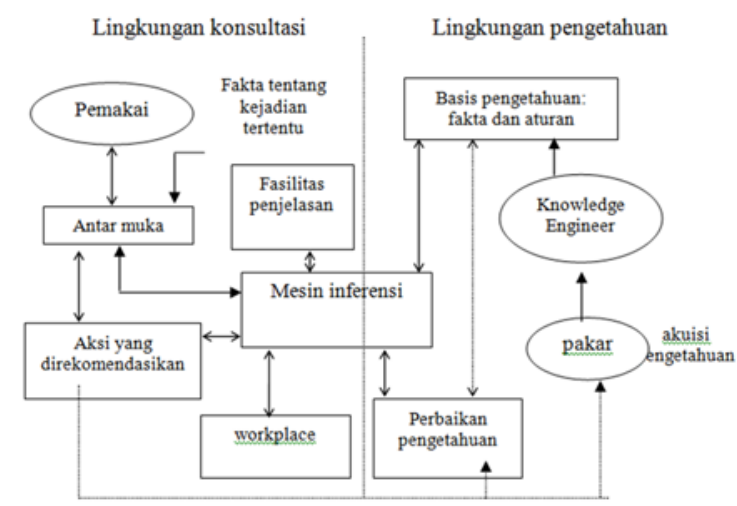

Gambar. 2. Konsep Dasar Fungsi Sistem Pakar

Ada dua tipe teknik inferensi yang ada yaitu pelacakan ke belakang ("Backward Chaining”) yang memulai penalarannya dari sekumpulan hipotesa menuju fakta-fakta yang mendukung hipotesa tersebut dan pelacakan ke depan ("Forward Chaining") yang merupakan kebalikan dari pelacakan ke belakang, yaitu memulai dari sekumpulan data menuju kesimpulan.

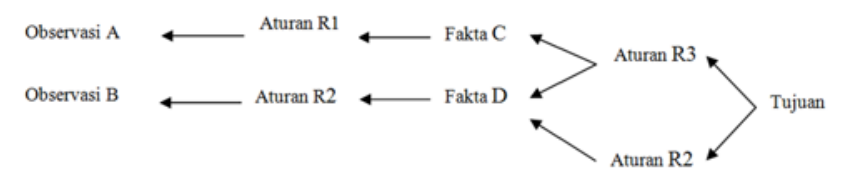

Gambar. 3. Proses Backward Chaining [2]

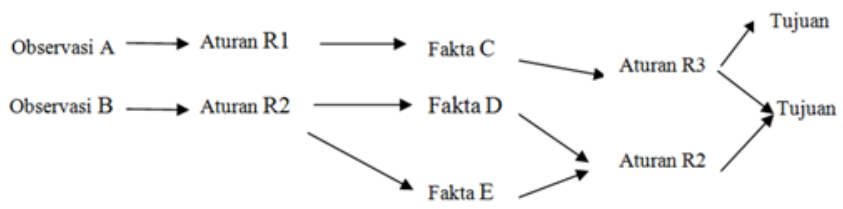

Gambar. 4. Proses Forward Chaining [2] 


\section{Metode PENELITIAN}

\section{A. Metode Pengumpulan Data}

1. Observasi

Mengadakan pengamatan dan pencatatan secara sistematis fenomenal-fenomenal yang diselidiki terhadap kondisi pertanian sehingga dapat dilihat kebutuhan aplikasi yang diinginkan serta pengambilan data yang akan digunakan dalam program yang dikerjakan.

2. Studi Literatur

Proses pembelajaran terhadap semua referensi yang berhubungan dengan setiap permasalahan dalam penelitian dan akan digunakan untuk penyelesaian seluruh rangkaian penelitian yang dilakukan dalam penyelasaian penelitian.

3. Inteview

Interview atau wawancara adalah proses tanya jawab mengenai permasalahan dimana ada dua orang atau lebih bertatap muka mendengarkan secara langsung informasi atau keterangan.

4. Browsing

Pengamatan keberbagai macam website untuk mendapatkan refrensi lebih banyak dan dalam perancangan sistem pakar dapat menghasilkan laporan yang akurat.

\section{B. Metode Pengembangan Sistem}

Dalam penulisan skripsi ini terutama dalam hal teknik pengembangan sistem. Metode yang digunakan penulis adalah:

\section{Analisis}

Analisis terhadap permasalahan untuk mengetahui kebutuhan serangkaian kegiatan dan teknik yang diperlukan serta menentukan batasan-batasan sistem, sehingga dapat menentukan cara yang efektif dalam menyelesaikan permasalahan.

2. Desain

Setelah menganalisa permasalahan selanjutnya dilakukan perancangan sistem dengan menggunakan model penanganan sistem yang telah diterapkan. memahami rancangan sistem pakar sesuai data yang ada dan mengimplementasikan model yang diinginkan para pengguna. Pemodelan sistem ini berupa blok diagram area permasalahan, pohon keputusan, serta perancangan database dengan didukung pembuatan context diagram, data flow diagram, ER-diagram dan flowchart, guna dalam mempermudah dalam proses selanjutnya.

3. Testing

Melakukan uji coba terhadap sistem dengan mendesain pengujian secara sistematis mengungkap kelas kesalahan yang berbeda dan melakukannya dengan jumlah waktu dan usaha minimum.

4. Dokumentasi

Membuat dokumentasi dan pengarsipan terhadap projek skripsi dalam bentuk laporan skripsi.

\section{DESAIN SISTEM}

Analisis berisi pengetahuan yang sangat diperlukan dalam mengembangkan suatu sistem pakar, Sehingga pada pelaksanaannya sistem pakar tersebut dapat menjalankan proses dengan baik sesuai dengan kebutuhannya.

Fakta pengetahuan yang disimpan yaitu pengetahuan mengenai jenis penyakit dan hama pada tanaman bawang merah serta pengetahuan mengenai manifestasi (gejala atau tanda yang muncul) yang menimbulkan tanaman terserang hama dan penyakit tesebut. oleh karena itu pada penelitian ini dilakukan beberapa analisis yang digambarkan menggunakan blok diagram.

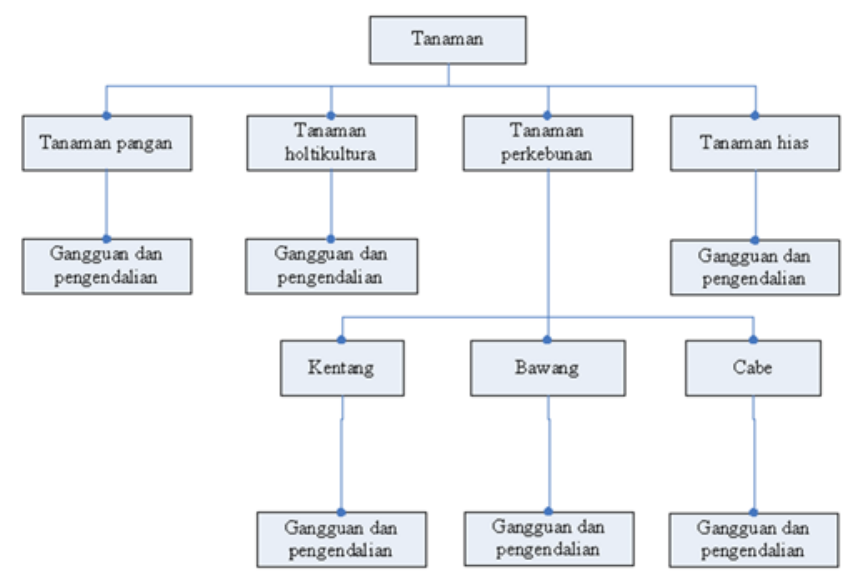

Gambar. 5. Blok diagram area permasalahan

Gambar 5 merupakan blok Diagram yang berfungsi untuk mengetahui dan membatasi ruang lingkup permasalahan yang akan dibahas dengan mengetahui posisi pokok bahasan pada domain yang lebih luas, Setelah mengetahui posisi area permasalahan yang di bahas dalam domain yang lebih luas, maka dilanjutkan dengan membuat blok diagram yang menjelaskan fokus permasalahan yang dibahas. Untuk lebih jelasnya bisa lihat pada Gambar 6

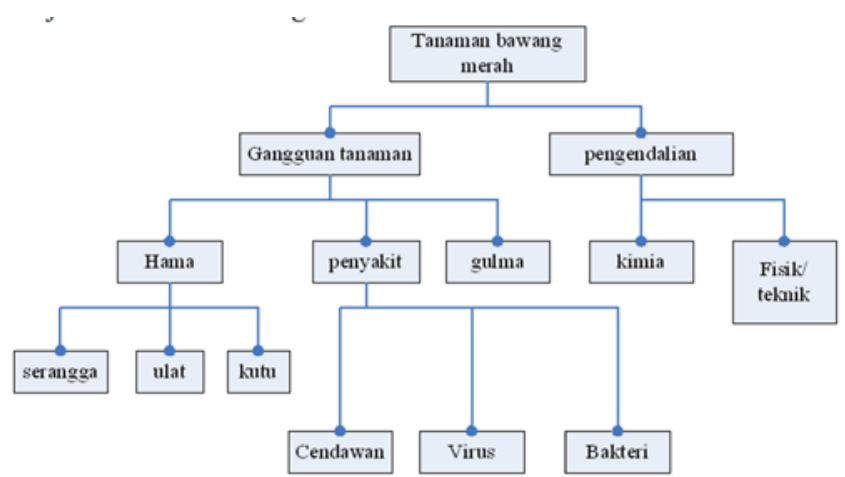

Gambar. 6. Blok diagram area permasalahan

Basis Pengetahuan (Knowledge base) terdiri dari representasi knowledge (pengetahuan) sebagai penalaran dalam penyelesaian problem/masalah yang biasa digunakan pada mesin pembelajaran (machine learning). Knowledge base atau basis pengetahuan kepakaran difungsikan sebagai pendukung pengambilan keputusan dari hasil pemrosesan pelacakan fakta, Sistem pakar pada penelitian ini menggunakan teknik forward Chaining yaitu teknik pencarian solusi dengan memulai proses pencarian dari sekumpulan fakta ataupun fakta, berdasarkan fakta yang 
didapat kemudian dicari satu kesimpulan yang nantinya diambil solusi dari problem / masalah yang dihadapi dengan beracuan pada rule-based reasoning.

Jika area permasalahan sudah jelas selanjutnya adalah merancang DFD (Data Flow Diagram), Data flow diagram Merupakan alat perancangan sistem yang berorientasi pada arus data dengan konsep dekomposisi dapat digunakan untuk penggambaran analisa maupun rancangan sistem yang mudah dikomunikasikan oleh profesional sistem kepada pemakai maupun pembuat program.

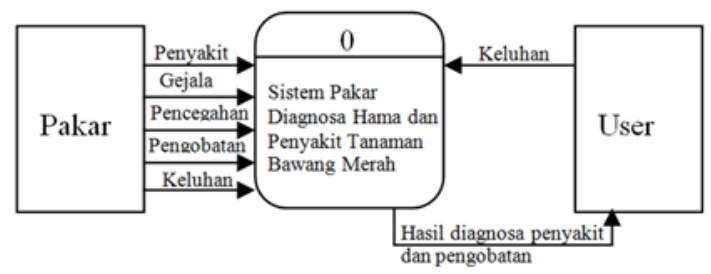

Gambar. 7. Konteks diagram DFD Level 0

Adapun jika DFD sudah selesai dirancang selanjutnya rancanglah ERD, Pada tahap ini dianalisa keterkaitan dan hubungan yang terjadi diantara entitas sistem pakar untuk identifikasi hama dan penyakit pada tanaman bawang merah.

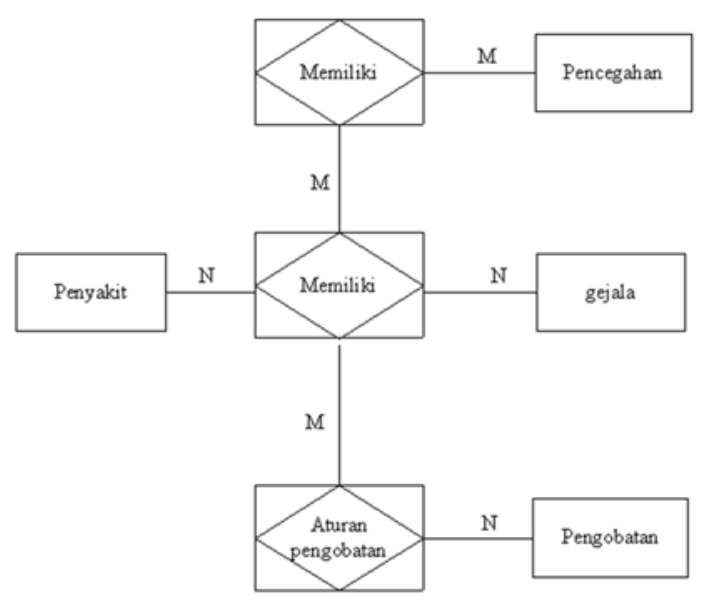

Gambar. 8. ERD Diagram

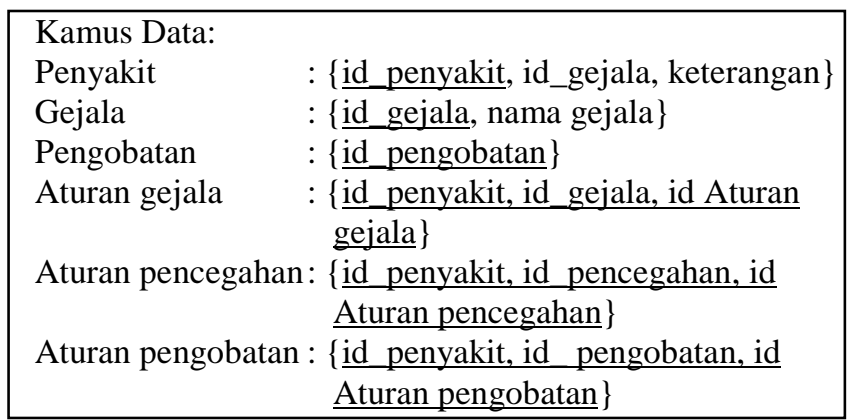

Saat pertama kali aplikasi sistem pakar dijalankan, maka tampilan form menu utama yang merupakan menu utama bagi user ataup. form ini digunakan untuk menempilkan menu-menu program aplikasi yang telah dirancang untuk menjalankan sistem pakar.

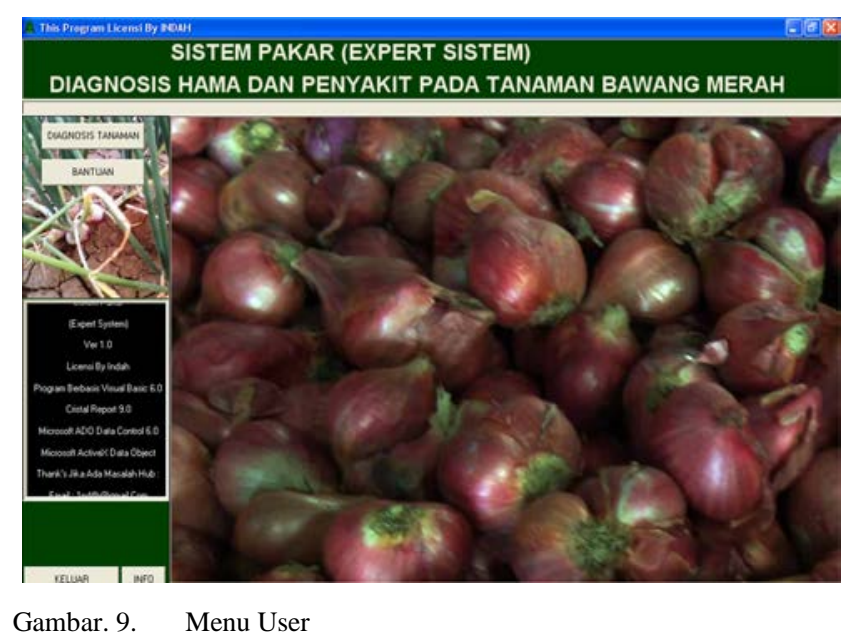

Untuk mendeteksi hama dan penyakit diperlukan input gejala, Menu ini digunakan untuk melakukan diagnosa berdasarkan gejala yang di inputkan user. Sistem pakar akan menampilkan beberapa ciri-ciri gejala yang tampak pada tanaman dan selanjutnya menampilkan pertanyaan pada setiap penelusuran yang dapat di pilih oleh user sehingga menghasilkan kesimpulan akhir yang berupa hasil pendeteksian.

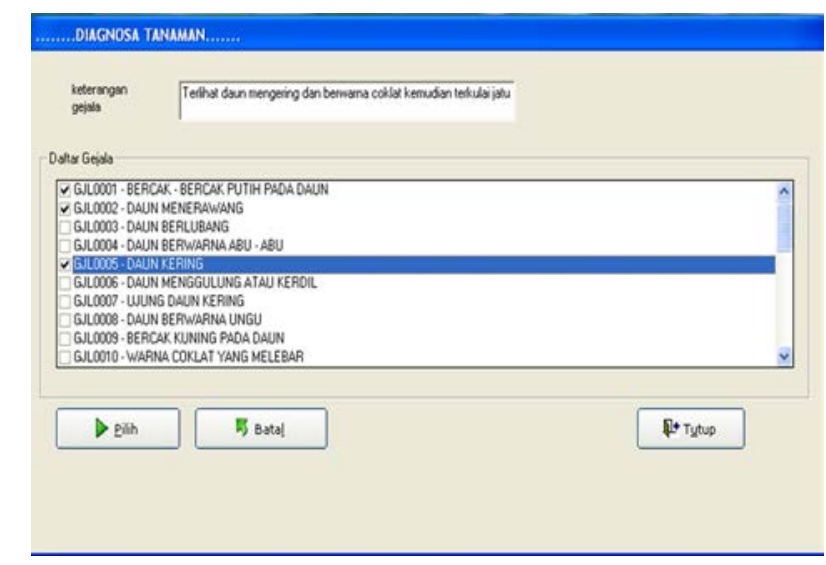

Gambar. 10. Input Gejala

Setelah memilih beberapa gejala dan menglick pilih maka akan tampil form yang akan menampilkan gejala yang telah dipilih user. Berikut adalah tampilan form daftar gejala.

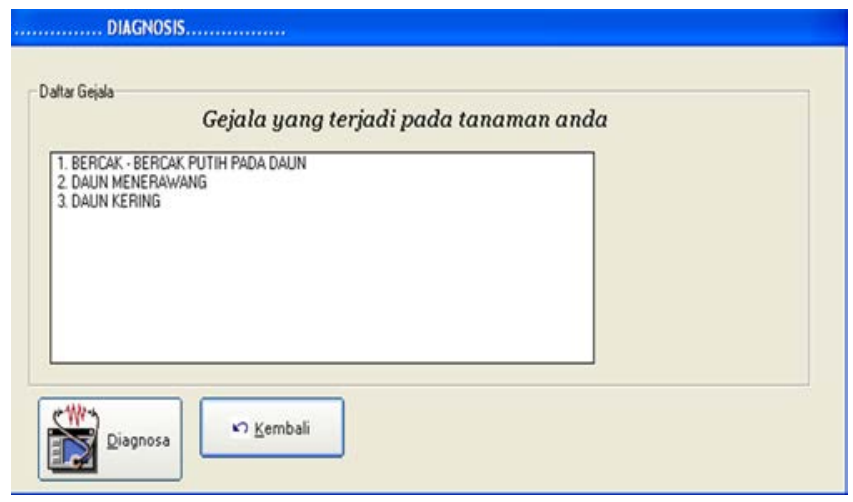

Gambar. 11. Gejala yang Dipilih 
Ketika memilih diagnosa muncul Form detail penyakit yang ini berisi tentang hasil penyakit dan sesuai dengan inputan gejala awal.

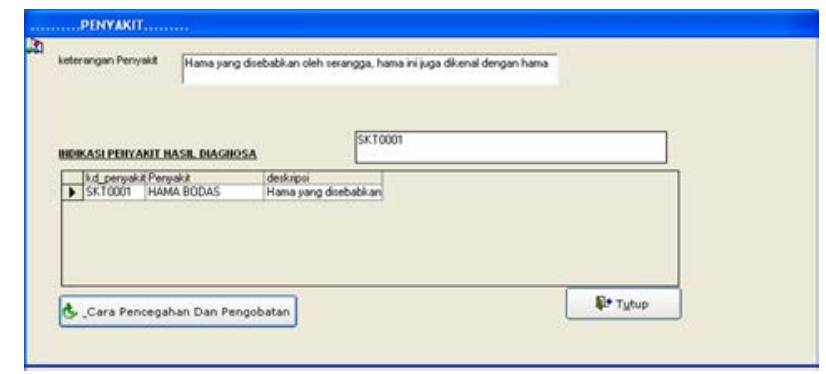

Gambar. 12. Hasil Diagnosa

Setelah mengetahui hasil indikasi penyakit yang terdeteksi, kemudian klik "Cara pencegahan dan pengobatan" untuk mengetahu cara pencegahan dan pengobatannya. Berikut adalah tampilan form dari pencegahan dan pengobatannya.

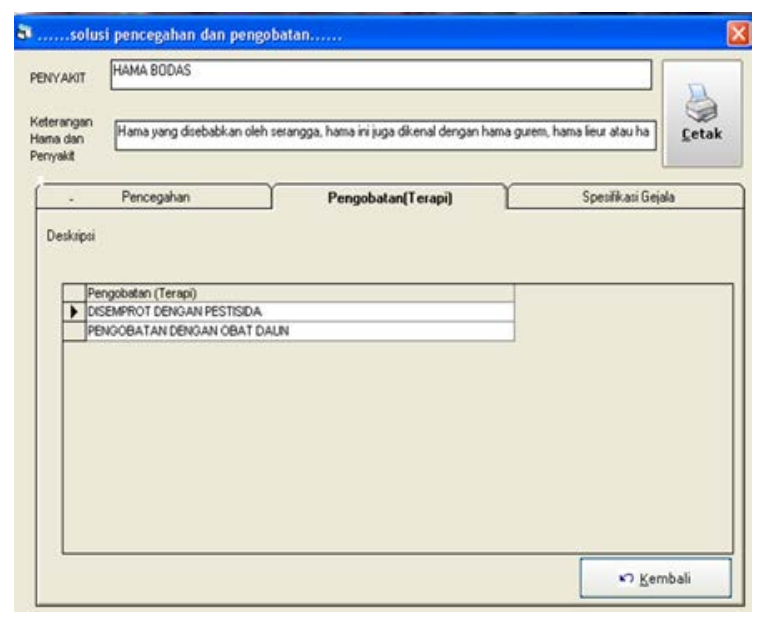

Gambar. 13. Solusi dan Pengobatan Hasil Diagnosis

\section{KESIMPULAN}

Adapun Kesimpulan dari hasil penelitian ini adalah sebagai berikut:

1. Sistem pakar yang dirancang dengan menggunakan bahasa pemrograman Visual Basic 6.0 ini mampu mendiagnosis atau mengidentifikasi hama dan penyakit yang menyerang tanaman bawang merah.

2. Pengendalian hama dan penyakit tanaman bawang merah sejak dini merupakan hal yang harus dilakukan untuk memperoleh hasil yang baik dan terhindar dari kegagalan panen.

3. Desain sistem pakar berbasis komputer merupakan salah satu usaha untuk memberika solusi pencegahan dan pengobatan yang harus dilakukan terhadap tanaman yang bawang merah yang terserang hama dan penyakit.

\section{DAFTAR PUSTAKA}

[1] Abdul kadir, "Pengenalan System Informasi," Andi,Yogyakarta,

[2] Anita Desiani, "Konsep Dasar Kecerdasan Buatan," Andi,Yogyakarta, 2006
[3] Fathansyah, "Basis Data,” Informatika Bandung, Bandung, 1999

[4] Hudi Matnawi, "Budidaya Tanaman Bawang,” Kanisus, Yogyakarta, 1997

[5] Rahmat Rukmana,”Bawang Meraj,”, Kanisuss, Yogyakarta,1994

[6] Singgi Wibowo,"Budidaya Bawang Beserta Hama Dan Penyakit Bawang,”, PT Penebar Swadaya, Bogor,1988

[7] Wahana Komputer,"Pemrograman Visual Basic 6.0,”,Andi Yogyakarta, 2003 